\title{
Experimental study on relationship between SOC and OCV of lithium-ion batteries
}

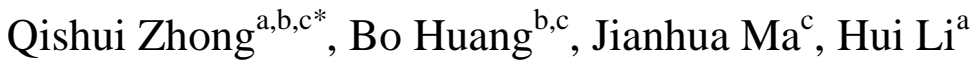 \\ ${ }^{a}$ School of Aeronautics and Astronautics, University of Electronic Science and Technology of China, Chengdu 611731, China \\ ${ }^{b}$ China Zhenhua Electronic Group Co Ltd, Guiyang 550018, China \\ ${ }^{c}$ Sinowatt Dongguan Limited, Dongguan 523696, China
}

\begin{abstract}
Electric Vehicles (EVs) are developed rapidly due to the energy and the environment problem. Lithium-ion batteries play an important role in energy storage system of EVs or other devices. The characteristics of power lithium-ion batteries are closely connected to ambient temperature. A battery testing system, including the charge/discharge device, the thermal chamber, DAQ card and etc, was constructed. With which, the experiments of 18650 cells and packs are carried out for the laws between SOC and OCV, also for the discharge capacity with different rates and ambient temperatures. These results can be used in battery management system (BMS) design for electric vehicles..
\end{abstract}

Keywords: Lithium-ion battery, state of charge (SOC), charge-open circuit voltage (OCV), temperature characteristics

\section{Introduction}

The rapid developments of automobile industry have brought people enormous convenience. However, automotive exhausts have been the main culprit of the air pollution in the urban area. On the other hand, as a kind of non-renewable energy, the petroleum and natural gas will be eventually exhausted in the near future with the consumption of them are rising. Energy saving and environmental protection have become the extremely prominent social problems [1]-[4].

The advent of the Electric Vehicles (EVs) and the Hybrid Electric Vehicles (HEVs) is to reduce energy consumption and environmental pollution caused by general vehicles. The adoptions of advanced power battery in electric vehicle are mainly Ni-Mh battery and lithium-ion battery [5]-[7]. Lithium-ion battery is characterize by high capacity, long life, high power density, and it will replace the present Ni-Mh battery to be the main energy storage system of the electric vehicle going with the declining costs [8], [9]. The economy is another very important aspect which will determine whether they can survive in the market competition. Meanwhile, the real-time and accurate estimation for the state of charge (state of charge, SOC) of the battery would have an impact on the economy of the hybrid electric vehicle [10], [11]. The estimation of SOC generally requires modeling of the battery cell and packs [12], the structure of the battery model and parameters identification should based on characteristics of charge-discharge test under different temperatures, which need sufficient test data of batteries. Equivalent circuit models in common use for lithium-ion battery are Thevenin model, RC model, and etc [13], as shown in Fig. 1.

The anode materials of lithium-ion batteries are mainly LiMnO2, LiFePO4 and LiCo1/3

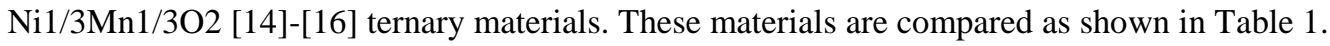

Ternary materials possess better performance in discharge voltage platform, specific capacity and compacted density compared with other two anode materials, which determine the energy density of the anode materials. Ternary material will own wider applications in power energy storage system of the $\mathrm{HEV}$ if the security performance of ternary lithium-ion batteries can be improved to a certain extent.

\footnotetext{
* Manuscript received July10, 2013; revised July 31, 2013.

Corresponding author. Tel.: +86-189-8056-1703; E-mail address: zhongqs@uestc.edu.cn.
} 


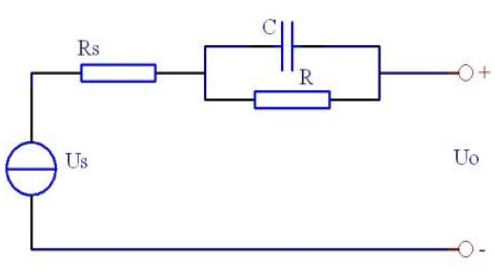

(a)

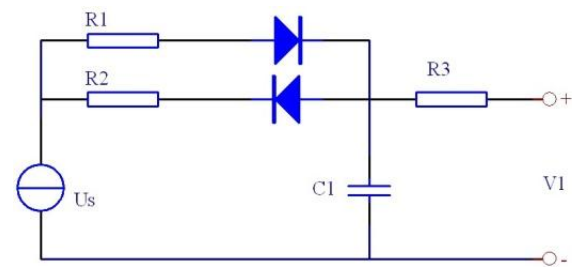

(b)

Fig. 1. Two common battery equivalent circuit models: (a) Thevenin model (b) RC model.

Table 1. Performance comparison for power batteries with different cathode materials

\begin{tabular}{lcccccc}
\hline \hline \multicolumn{1}{c}{ Materials } & $\begin{array}{c}\text { Security } \\
\text { performance }\end{array}$ & Circle life & $\begin{array}{c}\text { Discharge voltage } \\
\text { platform }\end{array}$ & $\begin{array}{c}\text { Specific capacity } \\
(\mathrm{mAh} / \mathrm{g})\end{array}$ & $\begin{array}{c}\text { Compacted density } \\
(\mathrm{g} / \mathrm{cm} 3)\end{array}$ & $\begin{array}{c}\text { Prices } \\
(\mathrm{dollar} / \mathrm{kg})\end{array}$ \\
\hline LiCo1/3 Ni1/3Mn1/3O2 & Good & Good & 3.6 & $145 \sim 155$ & $3.2 \sim 3.7$ & $\leq 26$ \\
LiMnO2 & Better & Good & 3.7 & $90 \sim 100$ & $2.7 \sim 3.0$ & $\leq 17$ \\
LiFePO4 & Better & Better & 3.2 & $120 \sim 140$ & $2.0 \sim 2.3$ & $\leq 26$ \\
\hline \hline
\end{tabular}

\section{Test Objects and Platform}

This paper uses the cylindrical 18650 ternary lithium-ion power battery, manufactured by Sinowatt Dongguan Co., Ltd, as the experimental objects to get the basic characteristics. Specifications of cells are as following: nominal capacity 2.0 Amper-hour, nominal voltage 3.7V and mass 41 grams. Cells and packs experiment platform should simulate the vehicle working condition, which we can get the experimental data in charge-discharge process to verify module's structure design and the validity of the design. The sketch of the experimental platform was shown in Fig. 2.

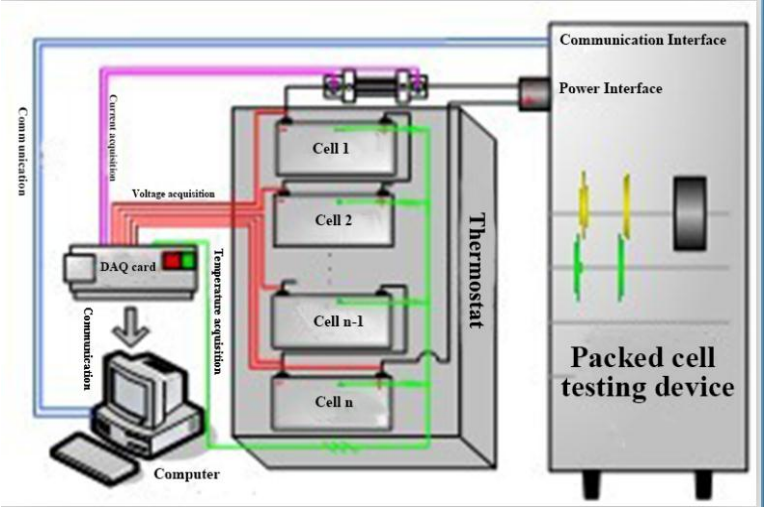

Fig. 2. The sketch of battery testing platform.

The experimental platform consists of five parts, including charge-discharge device of the battery, thermostat, data acquisition card, battery data record analysis and control computer, battery module. Computer can get and memorize the information (voltage, temperature and current) of batteries through the interaction with data acquisition card, we can analyze the state of battery, adjust charging method with data analysis software in computer and control the output of the charging-discharging device. The thermostat can hold temperature conditions for the test of the battery. The charging-discharging device provides the power source and the load for battery.

\section{Relationship between SOC and Open-Circuit Voltage}

\subsection{Battery cells test}

Open-circuit voltage is used to correct the estimated SOC, and this obviously play an important role in improving the estimate precision. Nine cylindrical 18650 power Li-ion battery cells were selected in the 
SOC and OCV relationship test. The test procedure is as follows: First, cells were fully charged and put them statically for about one hour for the steady state; then, cells were discharged with constant current and ensure to decrease SOC with 0.05 , measure the OCV after one hour, and discharge to decrease SOC with 0.05 . Thus we can get $21 \mathrm{OCV}$ values corresponding to SOC state from $1,0.95,0.90,0.85,0.80, \ldots$, $0.10,0.05$. The test curve of single cell was shown in Fig. 3. We can obtain the relation curve of SOCOCV, shown in Fig. 4 with nine cylindrical batteries respectively.

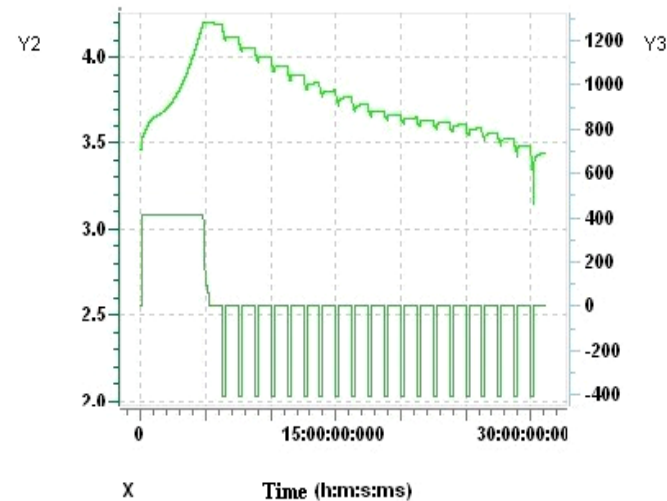

Fig. 3. SOC and OCV test.

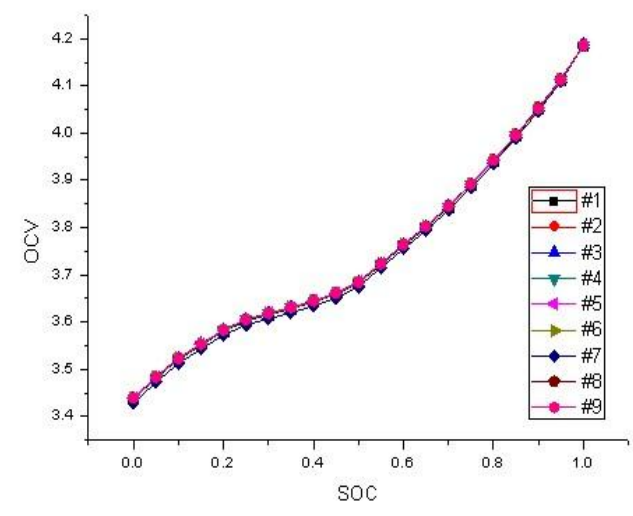

Fig. 4.Test results of 9 batteries's SOC and OCV.

The relationship between the SOC and OCV of the 18650 cells are nonlinear and we can use the OCV to estimate the SOC of battery. It is an appropriate method for using the OCV to estimate the initial SOC of battery especially after the EV stopped for an enough long time.

\subsection{Battery packs test}

18650 cells were selected for constructing two 5P10S packs to test the relationship between SOC and OCV. The testing procedure is the same as the above mentioned test procedure for cells and the test results were shown in Fig. 5. The battery packs can also keep a better consistency owing to the specified cells selection for packs.

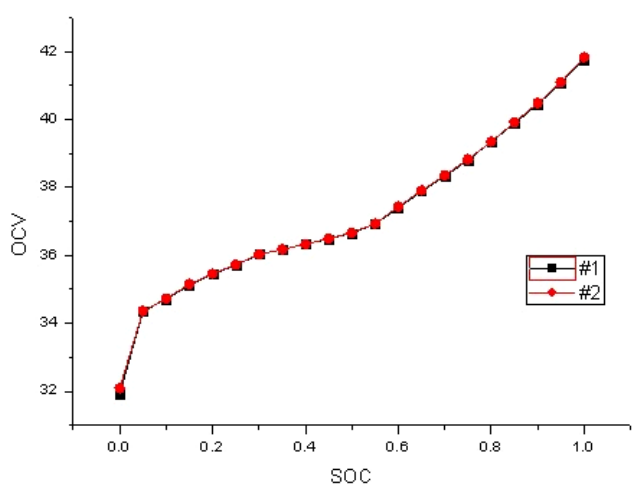

Fig. 5. Relationship between SOC and OCV of 5P10S packs.

\section{Capacity with Different Discharge Rate}

Battery system need to provide sufficient power when the EV is in climbing, launching, and accelerating, which means that high rate discharge current should be provided from battery system. To spy on characteristics of lithium-ion battery, we carried out the discharge tests with $0.1 \mathrm{C}, 0.5 \mathrm{C}, 1 \mathrm{C}$ discharge rate. Test results were shown in Table 2, the unit of the discharge capacity is $\mathrm{mAh}$, and the discharge time is second. 
Table 2. Battery capacity with different discharge rate

\begin{tabular}{ccccccc}
\hline \hline \multirow{2}{*}{ Cell number } & \multicolumn{2}{c}{$0.1 \mathrm{C}=207.5 \mathrm{~mA}$} & \multicolumn{2}{c}{$0.5 \mathrm{C}=1037.5 \mathrm{~mA}$} & \multicolumn{2}{c}{ 1C=2075 mA } \\
\cline { 2 - 6 } & $\begin{array}{c}\text { Discharge } \\
\text { capacity }\end{array}$ & $\begin{array}{c}\text { Discharge } \\
\text { time }\end{array}$ & $\begin{array}{c}\text { Discharge } \\
\text { capacity }\end{array}$ & $\begin{array}{c}\text { Discharge } \\
\text { time }\end{array}$ & $\begin{array}{c}\text { Discharge } \\
\text { capacity }\end{array}$ & $\begin{array}{c}\text { Discharge } \\
\text { time }\end{array}$ \\
\hline$\# 1$ & 2093.5 & 608 & 1964.8 & 113 & 1898.9 & 54 \\
$\# 2$ & 2077.7 & 603 & 1956.1 & 113 & 1894.8 & 54 \\
$\# 3$ & 2096.5 & 608 & 1980.5 & 114 & 1925.3 & 55 \\
$\# 4$ & 2077.4 & 602 & 1967.7 & 113 & 1908.9 & 55 \\
$\# 5$ & 2097.2 & 611 & 1975.5 & 114 & 1914.2 & 55 \\
$\# 6$ & 2082.6 & 601 & 1976.2 & 114 & 1921.3 & 55 \\
$\# 7$ & 2113.5 & 615 & 1994 & 115 & 1932.9 & 55 \\
$\# 8$ & 2100.7 & 614 & 1976.9 & 114 & 1918.5 & 55 \\
$\# 9$ & 2077 & 602 & 1966.5 & 113 & 1910.2 & 55 \\
Average values & 2090.68 & 607.11 & 1973.13 & 113.67 & 1913.89 & 54.78 \\
\hline \hline
\end{tabular}

From these data, one can know, with the increase of discharge current from the battery, the capacity of the battery are decreased, because of the concentration polarization increases, the voltage drop caused by internal resistance increases, the lithium also increase with the increase of the discharge current ,thereby result in the decrease of capacity.

\section{Capacity under Different Temperature}

Due to the working condition of the vehicle changes dramatically, we test the lithium-ion battery at $0.5 \mathrm{C}$ discharged rate in the following temperature: $-30^{\circ} \mathrm{C},-20^{\circ} \mathrm{C},-10^{\circ} \mathrm{C}, 0^{\circ} \mathrm{C}, 10^{\circ} \mathrm{C}, 30^{\circ} \mathrm{C}, 45^{\circ} \mathrm{C}$ and $55^{\circ} \mathrm{C}$. As shown in Table 3 and Fig. 6, the discharge capacity has an obvious increase with the rising temperature. It is because that the diffusion rate of lithium-ion in the battery is slow at low temperature, with the rising temperature the diffusion rate increased and the activity of cells will be enhanced. However, the high temperature will disorder the activity of lithium-ion, which will result in the increase of the internal resistance and the decrease of the discharge capacity.

Table 3. Battery Capacity with different temperature

\begin{tabular}{|c|c|c|c|c|c|}
\hline \multicolumn{2}{|c|}{ Cell number } & $\# 1$ & $\# 2$ & $\# 3$ & Average values \\
\hline \multirow{8}{*}{ 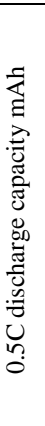 } & $55^{\circ} \mathrm{C}$ & 2163.6 & 2163.6 & 2172.3 & 2166.5 \\
\hline & $45^{\circ} \mathrm{C}$ & 2127.4 & 2123.3 & 2122.3 & 2124.3 \\
\hline & $30^{\circ} \mathrm{C}$ & 2048.9 & 2060.2 & 2069.8 & 2059.6 \\
\hline & $10^{\circ} \mathrm{C}$ & 1816.9 & 1814.3 & 1832.2 & 1821.1 \\
\hline & $0^{\circ} \mathrm{C}$ & 1590.7 & 1602.2 & 1591.0 & 1594.6 \\
\hline & $-10^{\circ} \mathrm{C}$ & 1378.9 & 1393.9 & 1398.9 & 1390.6 \\
\hline & $-20^{\circ} \mathrm{C}$ & 1030.4 & 1009.4 & 1027.7 & 1022.5 \\
\hline & $-30^{\circ} \mathrm{C}$ & 335.6 & 377.6 & 332.2 & 348.5 \\
\hline
\end{tabular}

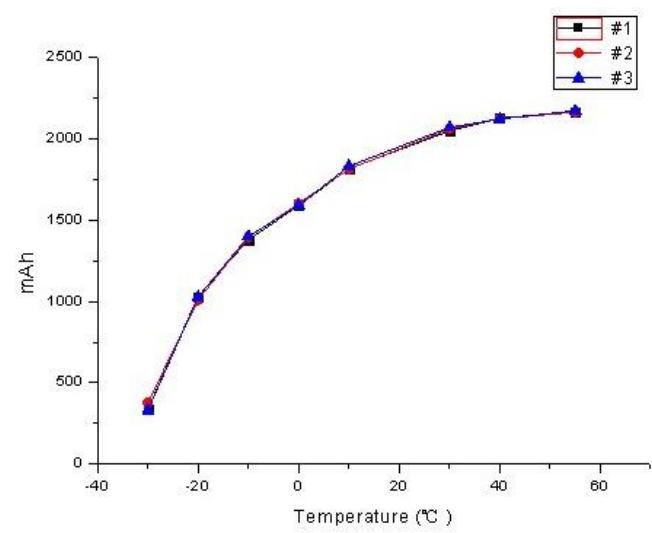

Fig. 6. Battery Capacity with different temperature.

\section{Conclusions}

In this paper, the relationship between SOC of Li-ion battery and OCV, discharge rate and capacity, capacity and temperature were investigated. The laws between SOC and OCV, the cell capacity with different discharge rate, the laws between capacity and temperature were proposed.

- The relationship between the SOC and OCV is nonlinear, we can use the OCV to estimate SOC, which can improve the estimated precision if we use the OCV to estimate SOC when in the downtime and adopt others estimations (Ampere-hour integral, Kalman filtering, and etc) when in the chargedischarge process. 
- With the increase of the discharge current and the concentration polarization in the cell, the voltage drop caused by the increasing internal resistance of the lithium-ion battery, thus, the discharge capacity of the battery will decrease with the increase of the discharge rate.

- The diffusion rate of lithium-ion in the cell is slow at low temperature. The activity of cells and the discharge capacity will increase with the rising temperatures.

Generally, one can use the equivalent circuit model to estimate the SOC of the power battery after identification parameters in the model. In this paper, performance data of the ternary lithium-ion power battery was obtained, with which, the unknown parameters of its equivalent circuit model can be identified, and these results can be used in battery management system design for electric vehicles.

\section{Acknowledgements}

This work was supported by the China Postdoctoral Science Foundation (2012M521683, 2013T60848), the Governor of Guizhou Province Talent Funds (2012), and the preliminary research fund.

\section{References}

[1] Liao X, He L, Zhong Z, et. al. A review of battery management system. Automotive Engineering, 2006; 28(10):961-964.

[2] Bhangu BS, Stone DA, Bingham CM. Nonlinear observers for predicting state-of-charge and state-of-health of lead-acid batteries for hybird-electric vehicles. IEEE Trans on Vehicular Technology, 2005; 54(3):783-794.

[3] Plett G. Extended Kalman filtering for battery management system of LiPB based HEV battery packs. Journal of Power Sources, 2004; 134(2):277-292.

[4] Liao B, Xiao FR. Progress of energy conservation and environment protection technologies in heat treatment. Heat Treatment of Metals, 2009, 34(11):1-6.

[5] Zhu H, Qian C, Xie YB, Li L. Parameter identification of MH/Ni power battery in hybrid electric vehicle. Journal of Hunan University( Natural Sciences), 2011; 38(8):19-23..

[6] LuL, Han X, Li J, Hua J, Ouyang M. A review on the key issues for lithium-ion battery management in electric vehicles. Journal of Power Sources, 2013, 226:272-288.

[7] Lee TK, Kim Y, Stefanopoulou A, Filipi ZS. Hybrid electric vehicle supervisory control design reflecting estimated lithiumion battery electrochemical dynamics. In: Proc. of American Control Conference (ACC), 2011:388-395.

[8] Katiyar RK., Singhal R, Asmar K, et al. High voltage spinel cathode materials for high energy density and high rate capability Li ion rechargeable batteries. Journal of Power Sources, 2009, 194:526-530.

[9] Zhang B, He YL, Chen QS. Energy and power characteristics analysis of lithium-ion battery for electric vehicle. Power Supply Technology, 2010, 34(10):1076-1079.

[10] Cheng KWE, Divakar BP, Wu H, et al. Battery-management system (BMS) and SOC development for electrical vehicles. IEEE Trans on Vehicular Technology, 2011, 60(1):76-88.

[11] He H, Xiong R, Zhang X, et al. State-of-charge estimation of the lithium-ion battery using an adaptive extended Kalman filter based on an improved thevenin model. IEEE Trans on Vehicle Technology, 2011, 60(4):1461-1469.

[12] Smith KA, Rahn CD, Wang CY. Model-based electrochemical estimation and constraint management for pulse operation of lithium ion batteries[J]. IEEE Trans on Control Systems Technology, 2010, 18(3):654-663.

[13] Du J, Liu Z, Chen C, Wang Y. Li-ion battery SOC estimation using EKF based on a model proposed by extreme learning machine. In: Proc. of IEEE Conference on Industrial Electronics and Applications (ICIEA), 2012:1651-1656.

[14] Zhao MS, Zhai YC, Tian YW. Study on kinetics of synthesizing spinel LiMn2O4 for lithium-ion battery cathode. Wuli Huaxue Хuebao, 2002, 18(2):188-192.

[15] Yim CH, Baranova EA, Abu-Lebdeh Y, Davidson I. Highly ordered LiFePO4 cathode material for li-ion batteries templated by surfactant-modified polystyrene colloidal crystals. Journal of Power Sources, 2012, 205:414-419.

[16] Kosova NV, Devyatkina ET, Kaichev VV. Optimization of Ni2+/Ni3+ ratio in layered Li(Ni,Mn,Co)O2 cathodes for better electrochemistry. Journal of Power Sources, 2007, 174(2):965-969. 